\title{
Artelogie
}

Recherche sur les arts, le patrimoine et la littérature de l'Amérique latine

5 | 2013

Femmes créatrices en Amérique latine : le défi de synthétiser sans singulariser

\section{The Art of Feliza Bursztyn: Confronting Cultural Hegemony}

Gina McDaniel Tarver

\section{(2) OpenEdition \\ Journals}

Electronic version

URL: https://journals.openedition.org/artelogie/5561

DOI: 10.4000/artelogie.5561

ISSN: 2115-6395

Publisher

Association ESCAL

Electronic reference

Gina McDaniel Tarver, "The Art of Feliza Bursztyn: Confronting Cultural Hegemony", Artelogie [Online],

5 | 2013, Online since 16 October 2013, connection on 20 December 2021. URL: http://

journals.openedition.org/artelogie/5561 ; DOI: https://doi.org/10.4000/artelogie.5561

This text was automatically generated on 20 December 2021.

Association ESCAL 


\title{
The Art of Feliza Bursztyn: Confronting Cultural Hegemony
}

\author{
Gina McDaniel Tarver
}

Figure 1. Photograph of Feliza Bursztyn with chatarra from El Tiempo, August 3, 1964

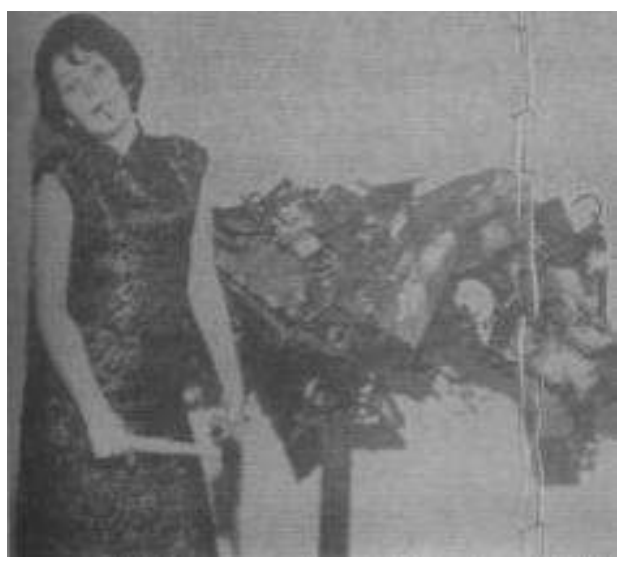

1 On Sunday, August 3, 1964, a photograph of the young Colombian artist Feliza Bursztyn (1933-1982) appeared in El Tiempo, Bogotá's largest daily newspaper (figure 1). The image shows Bursztyn with one of her chatarras (junk sculptures), a conglomeration of welded together, jagged scraps of rusty steel and broken machinery that explodes from a single stem like strange industrial foliage or a metalized mushroom cloud. Bursztyn, stylishly attired, stands in front of her sculpture, right hip thrust out, head cocked to the side, eyes wide and eyebrows raised, a cigarette hanging from her lips. With both hands she holds a hammer below her waist. The unusual accessory and casual pose, apparently captured mid-shrug, are at odds with her formal dress. She looks as though she is about to smash her sculpture, or already has, as if that violent act were part of the process of making it. This faded, gray image captures something of the ways in which Bursztyn irreverently and successfully smashed old artistic standards in the 1960s and 1970s in Colombia, of how, in the process, her work confronted deeply seated hegemonic cultural values. ${ }^{1}$ 
This photograph, among others, accompanied an announcement of prize winners for the Salón Intercol de Artistas Jóvenes, a national competition sponsored by Intercol (Colombia's subsidiary of the Standard Oil/Esso), held at the Museo de Arte Moderno de Bogotá in conjunction with the Pan American Union, and a prime example of the use of art in support of modernity. Bursztyn won the first prize for sculpture at this highprofile competition. ${ }^{2}$ It was the first prize she ever won, but only one among many in a distinguished but controversial career that ended abruptly with her unexpected death at age 49 .

3 Beginning with her chatarras in the early 1960s (figure 2) and continuing with related works throughout her career, Bursztyn's works disturbed many viewers because they clashed with dominant power structures that sought to control class and gender relations and morality. Seen from today's perspective, with the aid of decolonial theory, one can argue that what Bursztyn accomplished was the deployment of a kind of "border thinking"-a way of thinking (and producing) generated not necessarily from a literal geo-political border but from a position (or positions) designated as subordinate and excluded from power structures yet having to deal with those power structures. ${ }^{3}$ In other words, through her work with the material traces of modernity, Bursztyn made sensible her own experience of modernity-from her particular geographical position and as a Jewish woman in a patriarchal, Catholic, and "underdeveloped" country-and in doing so exposed modernity's darker side, coloniality. Ironically, what allowed Bursztyn to succeed in presenting a critical impression of modernity was the push, at the time, for greater industrial and artistic modernization in Colombia, the accompanying institutional embrace of the latest "international" art trends, and the visible similarity between Bursztyn's work and that of French nouvelles realistes such as César (with whom she trained) and Jean Tinguely. ${ }^{4}$

Figure 2. Feliza Bursztyn, Flexidra, c. 1965

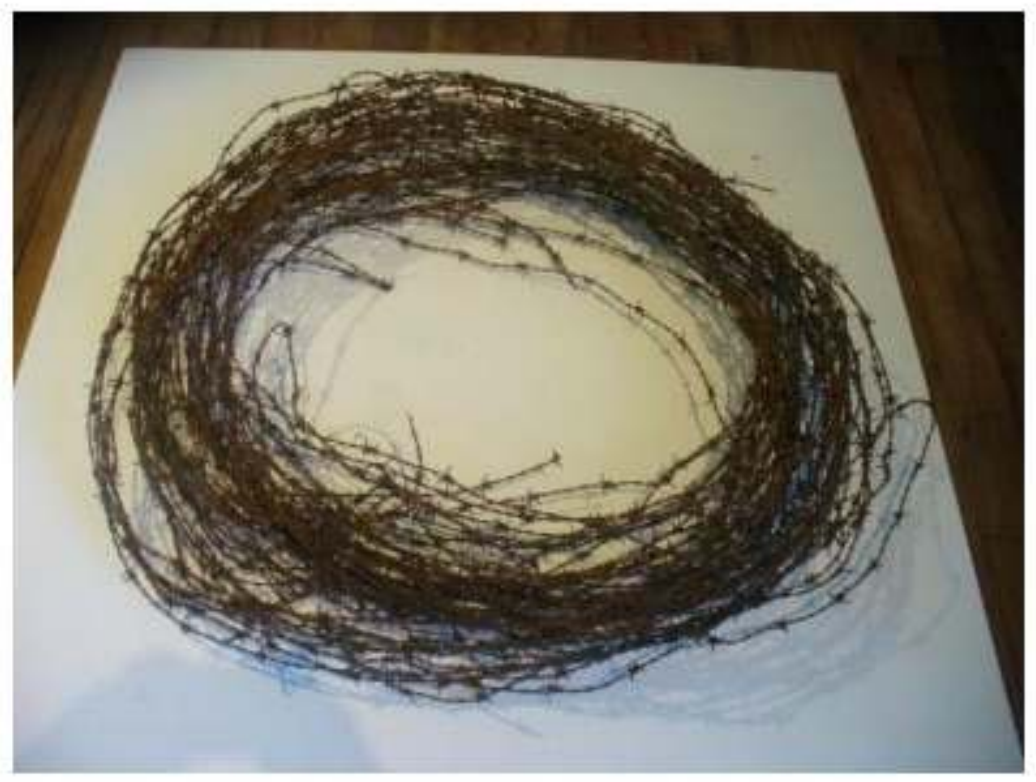

Assemblage (metal), $130 \times 130 \times 58 \mathrm{~cm}$ 


\section{The Status Quo}

4 To show how Bursztyn's art challenged hegemonic cultural values in Colombia, it is necessary to offer a sketch of the status quo. To begin with, art in Colombia when Bursztyn began her career was relatively conservative in comparison to modernism as it had developed in Europe and in other American countries like the United States, Argentina, and Brazil. It had been a struggle, in the 1950s, for critics such as Walter Engel, Casimiro Eiger, and Marta Traba (all immigrants to Colombia) to establish the validity of abstract art, which had not even emerged nationally before the 1940 s. ${ }^{5}$ Yet they had done it successfully by arguing that art should be judged as a form of individual expression based on universal, plastic values, ${ }^{6}$ and artists like Marco Ospina, Eduardo Ramirez Villamizar, Judith Marquez, Enrique Grau, and Alicia Tafur, among others, had gained national recognition for their abstract paintings and sculptures, while the idea of art as transcendent and autonomous, rising above specifically local concerns, also became well established in art criticism. ${ }^{7}$ No Colombian artist before Bursztyn used found objects as primary material for sculpture. ${ }^{8}$ The use of junk in and of itself entailed an obvious challenge to the norm, and her artwork disturbed in large part because of the material she used. It was precisely on the basis of material, though, that critics like Marta Traba-also director of the Museo de Arte Moderno de Bogotá and without a doubt the most influential figure in the Colombian art scene-argued that Bursztyn's art should be valued. Traba praised Bursztyn for her innovation and for integrating into art materials of "the new reality" of modern life. ${ }^{9}$ Few critics at the time even mentioned much less analyzed how Bursztyn's use of these materials of modern life related to a specifically Colombian modernity, and writers since have not given it detailed consideration, either. ${ }^{10}$

5 Colombia in the 1960s became increasingly modern, undergoing a period of rapid change. Its economy was still based in agriculture, with its largest export and source of income being coffee, but the nation, like others in Latin America, underwent an intense period of post-war industrialization, instituted as desarrollismo ("developmentism" or government policies for development). ${ }^{11}$ This meant that the manufacturing of consumer goods grew. ${ }^{12}$ With the growth of industry, the Colombia economy became a dual economy (agricultural/industrial), and that entailed certain contradictions and tensions. ${ }^{13}$ Industrialists had great power and were increasingly wealthy, but the landowning elite were still the most powerful group politically, and they preserved conservative values and supported the Catholic Church, which dominated in the areas of religion and education and thus had great influence on morality and sexuality, as well. ${ }^{14}$ Whereas the conservative elite harshly criticized modern art, the owners of private corporations, who tended to be more liberal, enthusiastically supported it, especially when it appeared to be new and young and to fit with international art trends. They saw such art as embracing the future and as a necessary part of the nation's development. ${ }^{15}$

6 While there were social, economic, political tensions between agricultural and industrial sectors of the elite, these groups nonetheless worked together in managing the nation and in most areas (art being an exception) maintaining the status quo. The 1960 s and 1970s in Colombia saw a growing discontent with the nation's elite, and many believed that the elite effectively formed an oligarchy despite Colombia's democratic political system. One very effective way that the elite controlled challenges 
to their power was through the establishment of the Frente Nacional (National Front), an agreement in effect from 1958-1974 under which offices in the Colombian government officially were shared between Colombia's two dominant parties (the Liberals and the Conservatives). ${ }^{16}$

7 Of course, this system handily excluded any other political factions including all Marxist groups. Those who held far-left political beliefs, such as Busztyn herself, were viewed with suspicion by the government and even, as shall be seen, persecuted. As in other countries, in Colombia political discontent showed itself with particular force on university campuses during the decade, as students protested developmental policies, imperialism, and the Viet Nam war. There were plenty of reasons-social, political, and economic-to protest the status quo. Despite consistent growth of the Gross National Product, poverty remained widespread. Development benefited the wealthy more than the middle class or poor, and income inequality had increased since 1938, reaching a peak in $1964 .{ }^{17}$ Both at universities and in the countryside, were there was a pressing need for agricultural reforms to protect the rights of small farmers and indigenous peoples, Marxist groups formed that, kept out of power by the Frente Nacional, sometimes took up arms, becomming Colombia's infamous guerrilla groups. Even after the Frente Nacional had ended in 1974, the government was able to justify persecution of Marxist individuals and groups as a response to increasing guerrilla activity. ${ }^{18}$

Bursztyn's artwork should be interpreted within this context. Although her artwork is abstract, through its material of "the new reality" and its new relationship to viewers, it can be linked to social issues. Bursztyn's ability to create an art challenging to the status quo perhaps was enhanced by her position as an affluent Colombian citizen yet one who, due to her heritage, did not fit the normal profile. Bursztyn was born to Polish Jews. Her parents were visiting Bogotá in 1933 when she was born, but on hearing that Hitler had been named Chancellor of Germany, the decided to stay permanently. ${ }^{19}$ Jews fleeing Nazism found a comfortable home in Colombia. In the 1950s, 1960s, and 1970s Colombian Jews experienced "formidable economic success" as merchants and manufacturers,,$^{20}$ and many Jewish immigrants became prominent intellectuals. ${ }^{21}$ Bursztyn's father had a small textile factory in Bogotá. Her family could afford the best education for her, and she studied in Bogotá, New York (at the Art Students League), and Paris (at the Académie de la Grande Chaumière). Beginning in 1960, Bursztyn took over the factory's garage as her studio. From her comfortable yet "outsider" position as a Jewish woman, daughter of immigrant industrialists, living next to a factory, she was able to flourish as an innovative artist with radical views.

\section{Chatarras}

9 In September 1961 Bursztyn unveiled her first eleven chatarras, relatively simple and flat compositions of rusted mechanical fragments such as wheels, hoops, nuts, bolts, spark plugs, gears, and wires, whose romantic and feminine titles, like Luna llena (Full Moon), Una flor (A Flower), and Niña alegre (Happy Girl), contrasted with their rough mechanical appearance. ${ }^{22}$ At their debut, they were not well received. Walter Engel, one of Colombia's foremost art critics, who was generally supportive of modern art, artistic innovation, and the Galería El Callejón where Bursztyn had her show, panned the exhibition. ${ }^{23}$ Engel's primary stated objection to Bursztyn's assemblages was what he saw as their lack of plastic value. His conclusion was harsh; he advised that Bursztyn 
should give up being a sculptor, since developing her chatarras into viable works of art would require a miracle.

It is difficult to assess the justice of Engel's vituperative review. Few images of her earliest chatarras have been published, and in 1961, no one else wrote about the exhibition, although several art historians since have noted that these chatarras represent only a timid beginning. ${ }^{24}$ The critic's severe assessment of her work, his accusation that the artist failed to convey her "own truths, as valid spiritually as plastically," may or may not have been justified, but at the least it reveals an uneasiness about junk as art material. ${ }^{25}$ Though Engel did not attack outright the material that Bursztyn used-indeed, he stressed that any proposal that is "well-said" becomes true art-one gets the sense that he was made uncomfortable by it, that perhaps his disgust with her work stemmed in great part from his aversion to the material she used and its origin. He repeatedly pointed out that the material was rusted and ruined. He also stated, in a manner that seems condescending, "I deduce that she has some connection to a mechanic's workshop," and that her sculptures seem to have been made "in the same workshop." ${ }^{26} \mathrm{He}$ seemed to feel that junk could not convey valid spiritual truths, which he took to be the role of art.

11 Her choice of junk as media provoked disdain, in part, due to its broken, rusted, corroded, and dirty appearance. The conservative view of art in Colombia and, even the liberal modernist view held that the art object should be a vehicle for aesthetic contemplation, emotive evocation, and even spiritual transcendence. But not only were these materials not nice to look at, they also lacked nobility. Although by the middle of the decade such materials would be accepted in Colombia, in no small part because many prominent artists internationally had adopted them during this period, their immediate effect within the local scene was that they offended. ${ }^{27}$ Looking back years after the chatarras were first exhibited, Marta Traba would argue, "From the first moment, a moral sanction, much more than an aesthetic sanction, weighed upon junk." 28

12 Bursztyn's adulterated materials seem to have disturbed also in their allusion to context, in the echoes of their former life. The junk was from the realm of industry rather than art. The French artist César, whom Bursztyn met while studying in Paris with Ossip Zadkine, directly inspired her use of junk. But as the artist asserted, this choice was ultimately a practical one. She explained that as an emerging artist in a country with little support for the arts, she turned to junk because it was more readily available and less expensive than more conventional artistic materials. ${ }^{29}$ Bursztyn's explanation accounts for both the force of international art as a model and the importance of local circumstances to an artist's formal decisions. It contradicts the simplistic and blindly chauvinist opinion expressed by Harold Rosenberg in 1964 that, “Whatever meaning a 'junk sculpture' may possess in London or Detroit, with their surpluses of manufactured products, a Mexican artist who exhibits a composition contrived of auto radiators and beer cans communicates chiefly that he is possessed by the tyrannical pace of world art and the fear of falling behind." ${ }^{30}$ Although Rosenberg used the example of a Mexican artist, he implicated any artist from an "underdeveloped" country who used junk..$^{31}$ On the contrary, while junk refers to industry, to economic development, and to a growing consumer culture, it also simultaneously can point to scarcity and the need to "make do" within the context of a low but growing level of modernization. It is a rusted reference, to a failed modernity of 
waste and deterioration, in great contrast to the clean, utopian view of modernity advanced by other Colombian sculptors like Edgar Negret (figure 3) or Eduardo Ramírez Villamizar (figure 4).

Figure 3. Edgar Negret, Aparato mágico (Magic Gadget), 1959

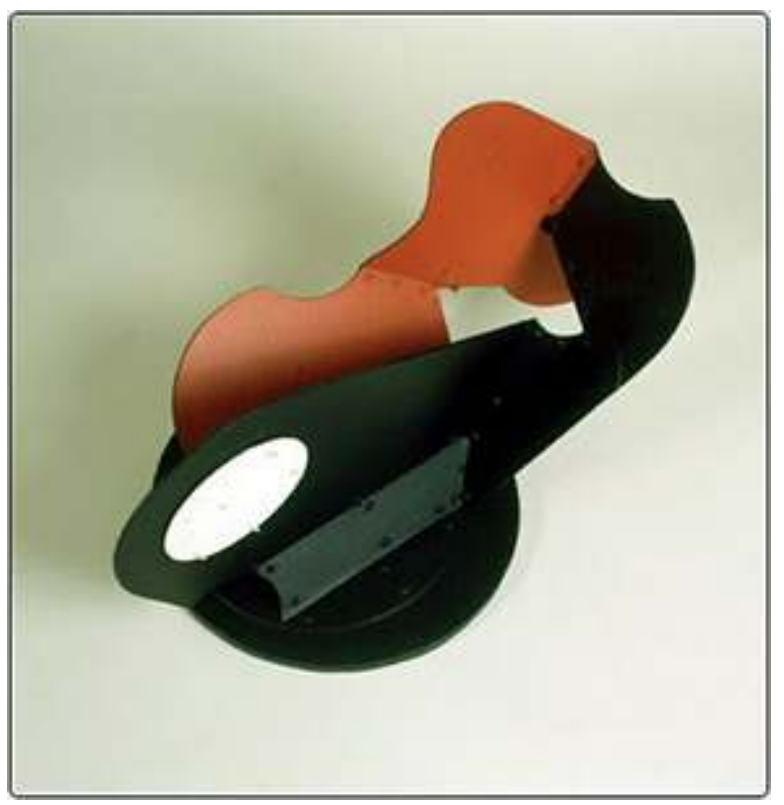

Polychromed wood and aluminum, $19 \times 35 \times 20^{\prime}$

Figure 4. Eduardo Ramírez Villamizar, Homenaje al poeta Gaitán Durán, 1964

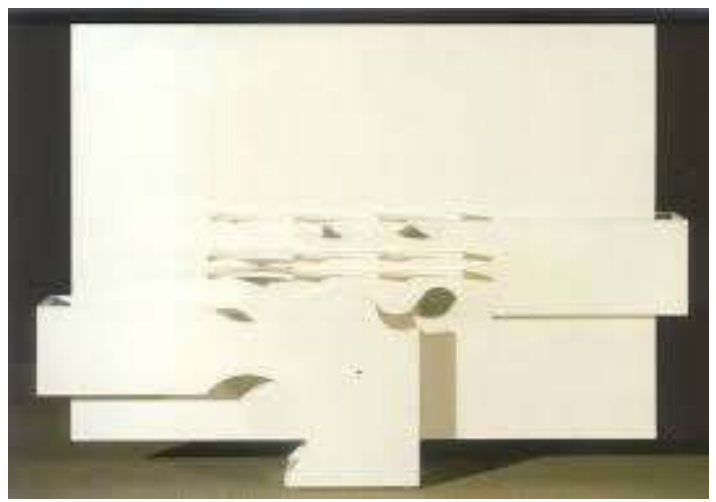

Painted metal, $185 \times 258 \times 44 \mathrm{~cm}$

With her dense accumulations made up of technological and consumer waste, Bursztyn critiqued the advent of a technological and consumer age in Colombia. In a rare review that mentions the local, from 1973, Eduardo Serrano would observe that her junk sculptures "forced thought in the presence of these materials that now poison a great part of [the Colombian] environment as a result of our incipient development." ${ }^{32} \mathrm{Her}$ work draws upon the irony that such durable material as metal makes up objects that so quickly become obsolete. Pieces of junk metal, like stripped, scattered, and dried out bones, mutely bear witness to the precariousness of the instruments of progress. The precarious quality of development was relevant in Colombia where, as elsewhere in 
Latin America during this period, industrial development was uneven, incomplete, and benefited the wealthy more than the poor. ${ }^{33}$

In response to the reality of widespread poverty, any metal scraps were recycled (and still are today). Many of Colombia's poorer citizens put salvaged metal materials to use, making television and radio antennas out of them, for example. The materials, once having one meaning and use, are given new meaning and use in a process that might be understood as bricolage, a method of production discussed by cultural anthropologist Claude Levi-Strauss. In opposition to the craftsman or engineer who acquires raw materials and develops tools for the purpose of the project, the bricoleur makes due with "whatever is at hand," employing various creative and "devious means" to address a given task. ${ }^{34}$ Creative reuse is common, and recycling is the main source of income for many people living in large cities, who search through trashcans for materials that can be sold. In salvaging scraps to make art, Bursztyn follows a popular tactic for making do in a poor country. Her works might be seen as referring to the ingenuity of people who, driven by necessity, reuse and recycle. But a celebration of the creativity of the poor is distressing to those who would rather not confront the reality of poverty, especially not in the museum or art gallery of the 1960s, a modern space consecrated to beauty, transcendence, and the promises of modernity.

Undoubtedly, the disturbing quality of Bursztyn's work was enhanced by the fact that she used materials that were not only associated with the ingenuity of the poor and the precariousness of progress, but also, by extension, with the proletariat. As is clear in Engel's review, the pieces of machinery she collected evoke images of mechanics in greasy coveralls, gripping wrenches in rough, dirty hands, working on the floor of a garage. Bursztyn's method of turning these scraps into sculpture by welding is also linked to the proletariat. It calls forth visions of workers, visors down and blowtorches up, toiling in a factory amidst bright clouds of sparks. Although Bursztyn herself (like most visual artists at the time) was from the middle-class, she was proud that her working methods were proletarian. She would proclaim as much in a 1974 interview published in a popular magazine, declaring, "I'm a worker and a solderer." 35

At the same time, she seems to have reveled in the apparent paradox of a middle-class female artist using proletarian methods, for the materials she uses and the technique of welding are associated not only with the working class but also, more specifically, with working-class men and male roles in society. ${ }^{36}$ The mechanic and the worker described above would most likely be male in Colombia in the 1960s. In fact, at this time, art itself was a profession still largely dominated by men. ${ }^{37}$ As the gallery owner Alonso Garcés would reflect years later, "Feliza faced an even greater difficulty [than male sculptors like Negret and Ramírez Villamizar] due to her being a woman in a society in which art made by women was related more to painting on porcelain than to soldering with an acetylene torch." ${ }^{38}$ Her adoption of welding as artistic technique exploded gender stereotypes. The delicate, feminine titles she gave her earliest chatarras served to emphasize this through contrast.

In multiple ways, Bursztyn's junk sculptures seem calculated to disturb, provoke, reject the status quo, push the limits. It is not surprising that, being a provocateur, she did not heed the advice of her critic in 1961 but continued to develop her chatarras (figure 5). Nor did it take her long to prove Engel wrong. She submitted junk sculptures to the following five national art salons, and each time they were accepted. Not only did one of them win a prize at the Salón Intercol, in 1965 another earned her the first 
prize for sculpture at the Salón Nacional, an annual competition sponsored by the Ministry of Culture and considered the nation's most prestigious art institution. With audacity, and with the help of Marta Traba (who was a member of the three-person prize jury for the 1965 Salón Nacional), she established herself as one of Colombia's foremost sculptors.

Figure 5. Clitemnestra, 1963

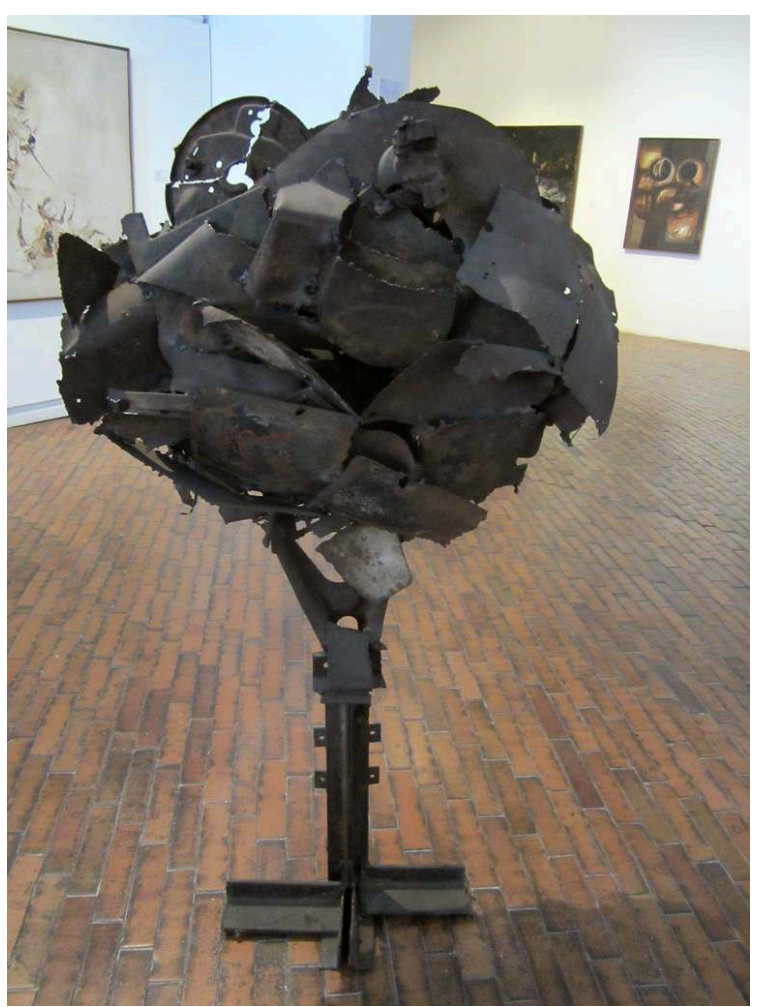

Soldered metal, $90 \times 156 \times 45 \mathrm{~cm}$

Collection Museo de Arte Moderno de Bogotá

\section{Las histéricas}

Bursztyn also became a pioneer of kinetic artwork in Colombia when she introduced a new kind of motorized sculpture in November 1967 with a series she called Las histéricas (The Histerics). ${ }^{39}$ Bursztyn debuted this new work in at the XIX Salón Nacional, where her Histérica No. 1 tied for third prize. ${ }^{40}$ To make Las histéricas, Bursztyn attached simple turntable motors to welded configurations of long, flexible metal bands (figure 6). Las histéricas not only moved, they made a great deal of sound as the thin metal strips, when put into motion, clashed together in a way that many found annoying and ugly. 
Figure 6. Feliza Bursztyn, Ensemblaje, 1968, 57 x 78 × $51 \mathrm{~cm}$

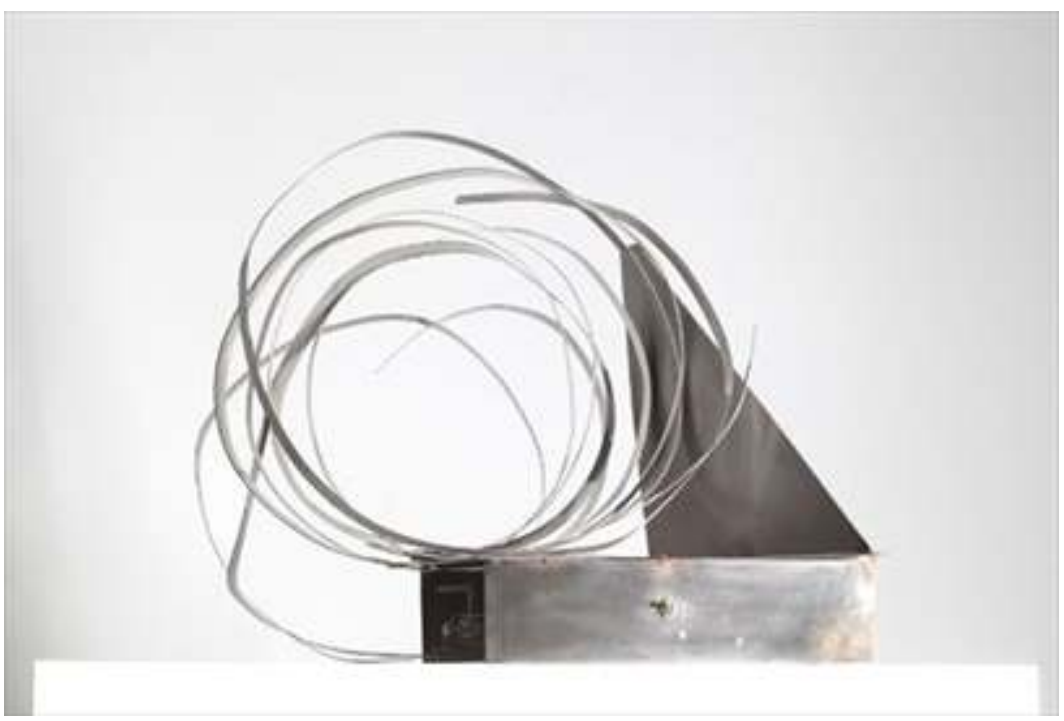

Bursztyn did not build Las histéricas out of the junk that had become her signature media, since her experiments with animating such junk proved unsuccessful. ${ }^{41}$ The flexible metal strips of Las histéricas, which Bursztyn bent into parabolic and circular configurations, are stainless steel. Bursztyn acquired most of them at a factory that made heaters. Her new material, though different from the junk she previously used, also had connections to industry. Furthermore, she left the works' motors visible. Their visibility, in addition to being anti-aesthetic, emphasizes the works' relationship to the world of machines. To make Las histéricas, she enlisted an electrician, a fact she announced in a newspaper interview. ${ }^{42}$ This technical collaboration added to the connections between her art and the working-class world.

Unlike motorized, industrial machines, Bursztyn's creations produce nothing more than movement and noise. ${ }^{43}$ These sculptures convulse in a startling manner, jangling irregularly. Their uselessness, the awkwardness of their movements, and the discordance of their sound combine to create darkly humorous works that have a discomforting effect on the viewer, like a stumbling, loud drunk at an elegant cocktail party. Through its reference to Freudian psychology, their title links them to female madness and to the disturbing depths of the human unconscious, while the material and motors mark such sexual references not as primal or primitive but as modern. Specifically, Las histéricas recall Freud's observations of hysterical women in the nineteenth century that formed the basis of his psychoanalytic theories and contributed key ideas to discourses of modernity. The reference strongly suggests that Bursztyn's sculpture is about female sexuality, repression, and modern social norms. ${ }^{44}$

The bright, sensuously curved metal strips that comprise the bodies of Las histéricas have a certain grace and beauty that are at odds with the naked motors and the abrupt movements and sounds these motors induce. Critics noted as much, some even arguing that the sculpture would have been better without movement. However, as Traba asserted, Bursztyn's goal was "the mortification or the exasperation of the public in order to push it to react with vitality." ${ }^{\prime 4}$ The disjunction between movement and form is important to the works' disquieting potential.

The nerve-rattling cacophony produced by Las histéricas, perhaps even more than their jerky movements or naked motors, was anti-aesthetic. For their first exhibition en 
masse, at the Museo de Arte Moderno de Bogotá in February 1968, Bursztyn distributed her motorized sculptures on all three floors of the museum, mounting some on the ceiling, some on the walls, and leaving others on the floors. She had them all clanking away simultaneously to ensure that the chaotic noise invaded every corner of the building. All galleries were darkened, too, and lit dramatically with spotlights that created reflections and shadows. Thus Bursztyn produced, for the first time in Colombia, a type of work that occupied space in a way that went beyond the material, evidence of the impact of the theater on her work and the fecundity that can result from cross-fertilization of the arts.

Bursztyn showed Las histéricas again at the Museo de Arte Moderno as her contribution to the Espacios ambientales (Environmental Spaces) group exhibition in December 1968-a landmark exhibition as the first in Colombia dedicated to environments, or what is today called installation art. Bursztyn painted the gallery for her environment, Siempre acostada (Always in Bed), which contained eleven Histéricas, completely black. ${ }^{46}$ She mounted one sculpture on the ceiling, one on the wall, and the remainder on the floor. Once again, she illuminated the space with spotlights, from the room's corners, walls, and ceiling. These lights would turn on and off intermittently, and as they did, they reflected off the metal sculptures causing them to shine in the darkness and cast ominous shadows. Concentrated in one dense nucleus, the sculptures again produced noise to extend the space they occupied beyond their material presence. Bursztyn's title for the environment heightens the sexual connotations of Las histéricas ("always in bed" but clearly not sleeping). And the darkened setting of Siempre acostada created a bedroom ambience. Through both title and setting, Bursztyn again made her interest in sexuality clear. Yet even though Bursztyn was by no means the only artist in Colombia to deal with erotic themes in the late 1960s, critics in the country, even the most sophisticated like Traba, ignored or overlooked her references to sexuality in 1968, either because the subject was taboo or because they simply had not yet developed the critical language to discuss it. ${ }^{47}$

Bursztyn also exhibited Las histéricas in June 1968 at the Festival de Arte in Cali and again in April 1969 at the Salón Cultural held in the gallery of the Banco de la República in Barranquilla. For these later exhibitions, too, she created an environment, with the addition of a short film by an experimental filmmaker from Barranquilla, Luis Ernesto Arocha, called Hoy Felisa [sic.]. The film featured shots of each of Las histéricas in action against a dark background, interspersed with still images of famous Hollywood stars Marlon Brando and Betty Davis, among other popular sex symbols. The film clarified the themes of drama and unattainable or unfulfilled desire..$^{48}$

\section{Radical Art and Politics}

That Bursztyn turned Las histericas into an environment in 1968 reveals not just the influence of theater but also an interest in creating a new relationship between the work of art and the spectator: art was now to be an experience that encompassed the viewer and engaged multiple senses. That is, it was to become more like other experiences in life, ideally more open with literally more space for the viewer. Espacios ambientales is evidence that this interest in expanding art and making it accessible to the viewer in new ways was growing within the Colombian art scene, with the support of important art institutions. 

and expanding sector of the elite-those who supported industrialism and internationalism-wished to promote. Statements made by corporate sponsors of the visual arts make clear that they felt it was their mission to assist in the cultural development of Colombia as part of the overall development of the countrydesarrollismo (developmentalism) being the driving force and entailing cultural as well as political and economic modernity. ${ }^{49}$ This meant, on the one hand, ensuring that Colombia was up-to-date in international terms, something that exhibitions such as Espacios ambientales, which itself was inspired by an exhibition of art environments held the previous year in Italy, helped to achieve..$^{50}$ It also meant, ideally, that Colombian culture should be accessible to all Colombians. While desarrollismo required some degree of greater cultural, social, political inclusion-it needed an expanded middle class to drive consumption-"democratic anxieties" that resulted from the cold war and the success of the Cuban Revolution also demanded inclusion through reform, lest revolution occur instead. The Colombian critic-curator Miguel González, writing in 1981, observed that "At the beginning of the past decade there still remained democratic anxieties that brought with them the illusion of an art for everyone. These were echoes of the Cuban experience that turned out to be attractive and exemplary, not without reason." ${ }^{51}$ González identified these democratic anxieties as belonging to exhibition organizers and artists alike. But whereas for corporate executives (members of the elite, who supported both modern art exhibitions and artists like Bursztyn), democratic anxiety stemmed, in great part, from a desire to stay in control, the artists generally wanted to break down rather than preserve existing power relations, many even aligning themselves with Marxist ideas of radical structural change (Bursztyn openly declared that politically she leaned to the extreme left)..$^{52}$ It made for a complicated relationship between artists and institutions and between art and society. forces of the Colombian government; she was suspect not necessarily because of her art but due to several trips she took to Cuba. Authorities detained and questioned her for the first time in 1967, upon her return from a journey that included stops in Europe, Israel, and Cuba. ${ }^{53}$ When in 1969 she was asked in an interview about the connection between her art and politics, Bursztyn expressed a belief that her sculpture was very different from her political position, that the two could not be equated, although the interviewer reported that Bursztyn "also believes that every manifestation of man is always political, because in our age all manner of human behavior constitutes the political." ${ }^{54}$ So in what way may Bursztyn's art have constituted the political?

The desire to make art into something new and more open to viewer participation on the part of artists like Bursztyn might be interpreted in the light of leftist politics as expressing a desire for inclusion and even liberation of individual subjects (the viewers). ${ }^{55}$ And yet Bursztyn's environment, Siempre acostada, in common with the other environments of Espacios ambientales, was based, at least partly, on disorientation and confusion and therefore might be considered unpleasant and aggressive toward the viewer rather than open and inclusive. Proclaiming her pride at being the exhibition's organizer, Traba described it as "an attack on the passivity of the public." ${ }^{56}$ She went on to aver, "One can't continue saying that a radical change has affected art and the spectator-work of art relationship. It must be demonstrated. The museum's exhibition is the first attempt to demonstrate it." ${ }^{57}$ This radical new art aggressively confronted 
and disrupted while also inviting a new degree of activity on the part of the viewer. Could it be seen as having revolutionary implications outside as well as inside of the art gallery?

At least some potential viewers of Espacios ambientales did not think so. Members of a leftist student organization felt this new art was no less elite than more conventional ones; they did not believe the exhibition was appropriate given the problems of poverty, inequality, and injustice plaguing the country. Accordingly, for the exhibition's opening, they staged a protest at the museum's entrance under the slogan "an art for the people and not for the bourgeoisie." ${ }^{58}$ Then, in the early hours of the morning following the opening, two members of the group broke into the museum and began smashing works before they were detected and arrested by the police.

Traba responded with a statement to the media that expressed her sympathy with the ideals of the students while deploring their means, and by organizing an open forum at which the artists and the public could discuss the exhibition. She voiced her opinion on the importance of art as a means of enriching the vision and knowledge of humankind, stating that "the exit from underdevelopment, in whatever political situation that a country lives, capitalism or socialism, authoritarianism or popular revolution, cannot be achieved except through multiple routes... and any other conduct favors the economic, cultural, and political status quo that has prevailed in Colombia since the colonial times." ${ }^{59}$ Traba, as many others of her time, believed that the way to solve the problems of "underdevelopment" was through development. Traba's holistic view of development as expressed in December 1968 is strikingly similar to that of contemporary industrialists and politicians, however different her political goals were. ${ }^{60}$ In other words, she believed that modern art had a role to play in achieving modernity.

31 Such was Traba's belief, which represents a dominant institutional view in Colombia at the time. It is a theory that allows Bursztyn's art to be interpreted within the discourse of modern art as developed in Europe and adopted in the Americas. But an alternative reading could focus on the ways in which her art complicated and critiqued, rather than complimented, the European-American modernist project. Rather than perceiving her art as contributing to the progress of Western culture, it can be conceived of as representing a counter-cultural proposal of an alternative to the hegemonic norm, although complicated by certain leftist expectations of what dissenting art should be like.

\section{Minimáquinas}

After all the strident noise and boisterous motion of Las histéricas, and the turbulence that marked the opening of Espacios ambientales, the Minimáquinas (Minimachines) that Bursztyn exhibited at the Galería San Diego in Bogotá in the late fall of 1969 must have seemed surprisingly timid, reserved, and perhaps at first glance even relatively conventional (figure 7). As their name implies, these are modestly sized and mechanical-looking sculptures, whose dimensions ranged from about 10 to $30 \mathrm{~cm}$. They are intricate structures, made from disassembled typewriters and other small manual machines. To compound the preciousness lent them by their detail and, often, delicacy, Bursztyn spray-painted some of them gold and silver. Since before launching the chatarras in 1961, Bursztyn had not worked on such an intimate scale, and the scale and 
precious appearance of the Minimáquinas magnetically draws in the viewer, as to a treasure to be examined and appreciated quietly, up close, perhaps in solitude and certainly on an individual basis.

Figure 7. Feliza Bursztyn, from the series Minimáquinas, 1971

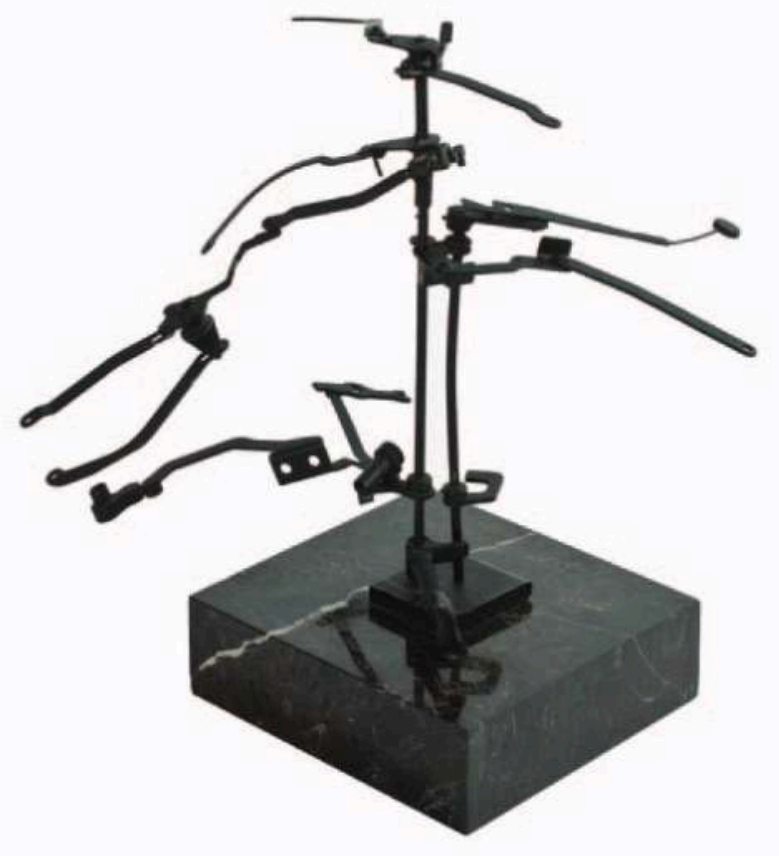

Metal junk sculpture, $17 \times 14.5 \times 12 \mathrm{~cm}$

One other characteristic also calls the viewer into a close intimacy with the work. These Minimáquinas have moveable parts that viewers could manipulate. Especially when handled, many take on an animate and often humorous quality so that they seem almost like small animals. Organic and open to alteration, the Minimáquinas are comparable to the Brazilian artist Lygia Clark's Bichos (Critters) of $1960 .{ }^{61}$ Like the earlier Bichos, they establish an active relationship between viewer and work. Viewer participation through manipulation of the artwork was not entirely new in Colombia, encountered previously in Bernardo Salcedo's Autopistas '69 (exhibited in December 1968) and Jacqueline Nova and Julia Acuña's Luz, sonido, movimiento (March 1969) for example, but the invitation to participate presented by the Minimáquinas is subtle and intimate, the very opposite of the invasive, spectacular, and encompassing, even demanding kind of invitation previously issued. There are many possible configurations that could result from the manipulation of the Minimáquinas, none of them the "right" one, and all of them lasting as sculptural form until the next viewer makes a change. These quiet sculptures, then, also expanded art in a new direction through viewer participation, this time a participation that is about an individualized, two-part dialog rather than public confrontation or spectacle. Bursztyn would continue to create Minimáquinas at various times throughout the 1970s.

In 1971, the Minimáquinas inspired the filmmaker Arocha to make another short film, titled Azilef ("Feliza" spelled backwards), featuring Bursztyn's art. ${ }^{62}$ Both the machine- 
like and zoomorphic qualities of the Minimáquinas come across in this eight-minutelong black and white film, and it clearly links Bursztyn's works to aspects of youth counter-culture, which had recently emerged in Colombia. In Azilef, the Minimáquinas appear to be alien creatures, spaceships, or satellites that move through empty black space. The film's soundtrack was composed and performed especially for the project by the Bogotá-based, Beatles-inspired rock band Los Teipus and includes a psychedelic folk-rock song, with lyrics in English about magic, dreams, love, the universe, and possibilities. The song, the outer-space theme, and the appearance, in the last seconds of the film, of a floating marijuana plant all locate Bursztyn's work in relation to hippismo (hippyism), with its rejection of convention, ideas of sexual freedom, renunciation of materialism, experimentation with drugs, embrace of new popular art forms (especially rock music), and utopian belief in the possibility of a better future. Hippismo represented a cultural, rather than explicitly political, challenge to the status quo, but like political challenges, it was taken as a serious threat, as evidenced by the negative reactions that the hippies garnered. ${ }^{63}$ Rather than representing a contraction or scaling back of her previous confrontational approaches, then, the Minimáquinas can be seen as representing a different yet still expansive and challenging means of countering hegemonic culture.

\section{Las camas and La bailamecánica}

Atlhough Bursztyn dedicated only a brief period to developing Las histéricas (19671968), she would continue a short time later to experiment with some of the innovations Las histéricas introduced. Both motorized movement, with its resultant anthropomorphic suggestiveness, and the staging of her work using light and sound were important elements in later works, especially Las camas (The Beds, 1974) and La baila mecánica (The Mechanical Dance, 1979).

For Las camas, an exhibition which debuted on March 26, 1974 at Museo de Arte Moderno de Bogotá and later was shown at other venues, Bursztyn attached hidden motors to thirteen beds. ${ }^{64}$ On the beds were strange forms, completely hidden underneath shiny satin sheets (figure 8). The colors of the coverings were significant. A review of Las camas noted how one set of beds sported yellow, blue, and red covers (the colors of the national flag), with others covered in an "attractive bishop purple," while in another area of the exhibition, all the beds were neutral in color, somewhere between an "ice white and pale lilac," and that in regard to the symbolism of the colors "an obvious interpretation would be: the State, the Church, and the People." ${ }^{55}$ Bursztyn presented Las camas, like Las histéricas before them, with dramatic spotlighting in a darkened and carefully prepared setting (surrounded by black curtains). Las camas also had a musical soundtrack, created especially for Bursztyn by the experimental electronic musician Jacqueline Nova, whose music more than one critic had already compared to the noises made by Las histéricas. ${ }^{66}$ The wildly jerking beds, sensual coverings, and darkened surroundings of Las camas meant that they, even more than the Las histéricas, flaunted the theme of sexuality, still a taboo theme in such a heavilyCatholic country, and the colors linked sexuality (and/or its repression) to social institutions like the church. 


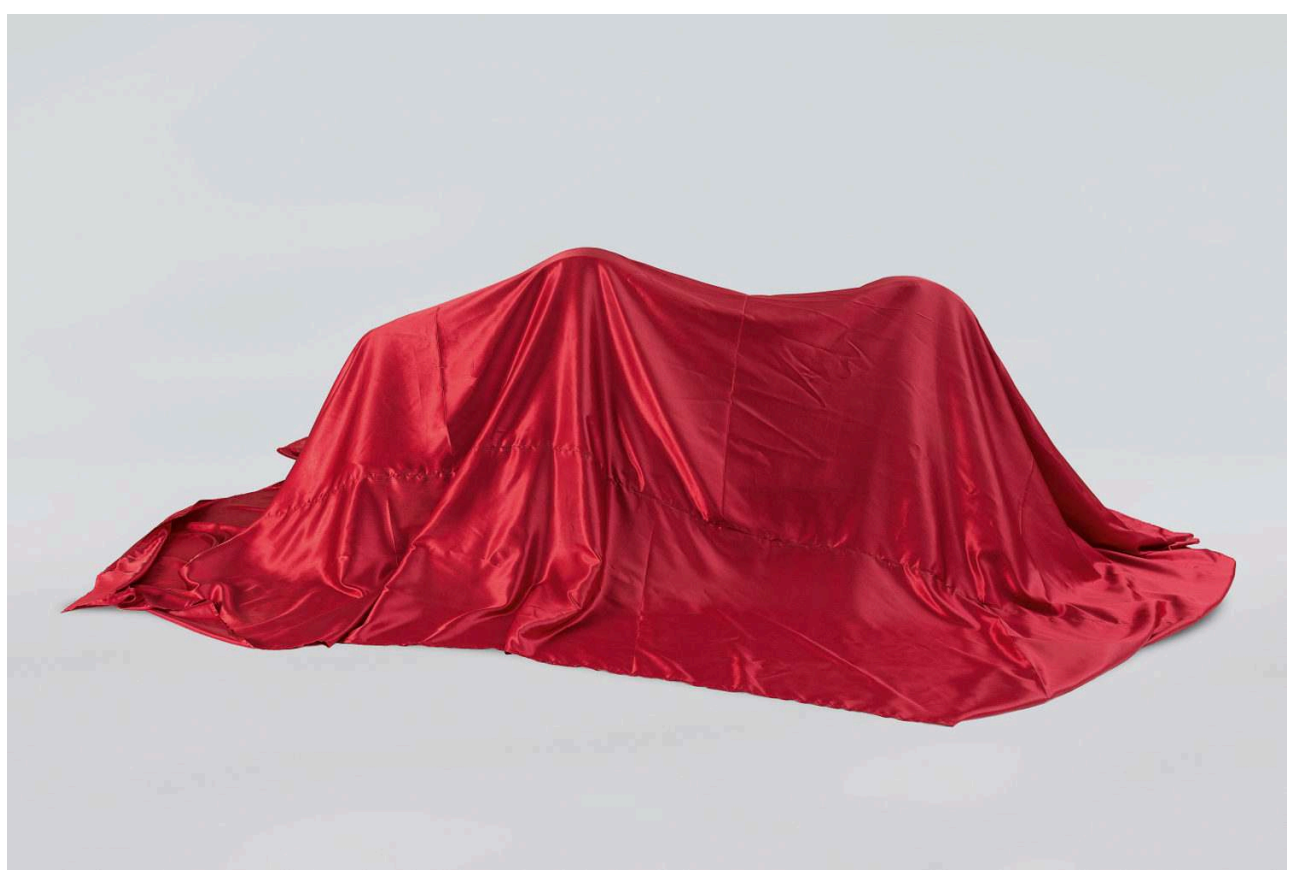

Whereas critiques of Las histéricas, in 1967-1968, stuck to general observations about form, novelty, movement, and irritating effects, seven years later Las camas, with their more obvious eroticism, did elicit allusions to, if not direct discussion of, sexual matters. Critic Nicolás Suescún, in a review published two days before the exhibition opening, never explicitly mentioned sex, but he did write that Las camas made him think of "pairs of copulating robots" and that they suggested "a common enough act that usually takes place in bed." ${ }^{67} \mathrm{He}$ recognized that Las camas were seen as an attack both on art and conventional values and anticipated the scandal they could cause, writing with sarcasm that, "Fortunately, there is still time to thwart the dark conspiracy. The Society of Improvements and Beautification, the Censorship Board, and all the institutions and individuals that still love the Fatherland must write letters on the matter before it is too late...." ${ }^{68}$ Suescún's irony comes through strongly in this passage as he mockingly suggests that those who want to preserve the culture of the "Fatherland" still have time to protest. Traba, too, commented briefly, albeit through a philosophical reference, on the role that sexuality plays in Las camas. She called the spectacle of the exhibition a "liberating experience, that could well illustrate the great theme of our century: eros and civilization." ${ }^{69}$ Traba was referring to the German philosopher Herbert Marcuse's famous book Eros and Civilization: An Inquiry into Freud (1955), wherein he puts forth a vision of a liberated (non-repressed) society based on a Marxist revision (and reversal) of Freud's theory of the role of repression in civilization. Traba was deeply influenced by Marcuse and would write, in the 1970s, of the liberating power of eroticism in art, although still keeping her critique "universal" by avoiding discussion of a specifically Colombian context. ${ }^{70}$

Bursztyn's next kinetic work, La baila mecánica (figure 9), which she first showed at the Galería Garces Velásquez on April 5, 1979, is not blatantly erotic like Las camas. La baila mecánica created the impression of an ongoing struggle against repression or even oppression, also through the mechanical anthropomorphism of moving forms completely covered in draped cloth-the cloth in this instance not bright and flashy 
like the material of Las camas but more common, being dull, stained, and wrinkled in appearance. For this installation, she created seven large (roughly human-sized), upright, and mysterious "figures" that she humanized and individualized by giving them each a name. Each figure had a hidden motor, connected to the ceiling with a visible power cord, that made it "dance" on a stage, for twenty minutes at four set times during the day, to medieval music. Even the exhibition brochure reflected the theatricality of this work, since it mimicked a playbill, complete with a cast list.

Figure 9. Feliza Bursztyn, La baila mecánica, 1979, as installed at the Galería Garcés Velásquez, Bogotá, 1979

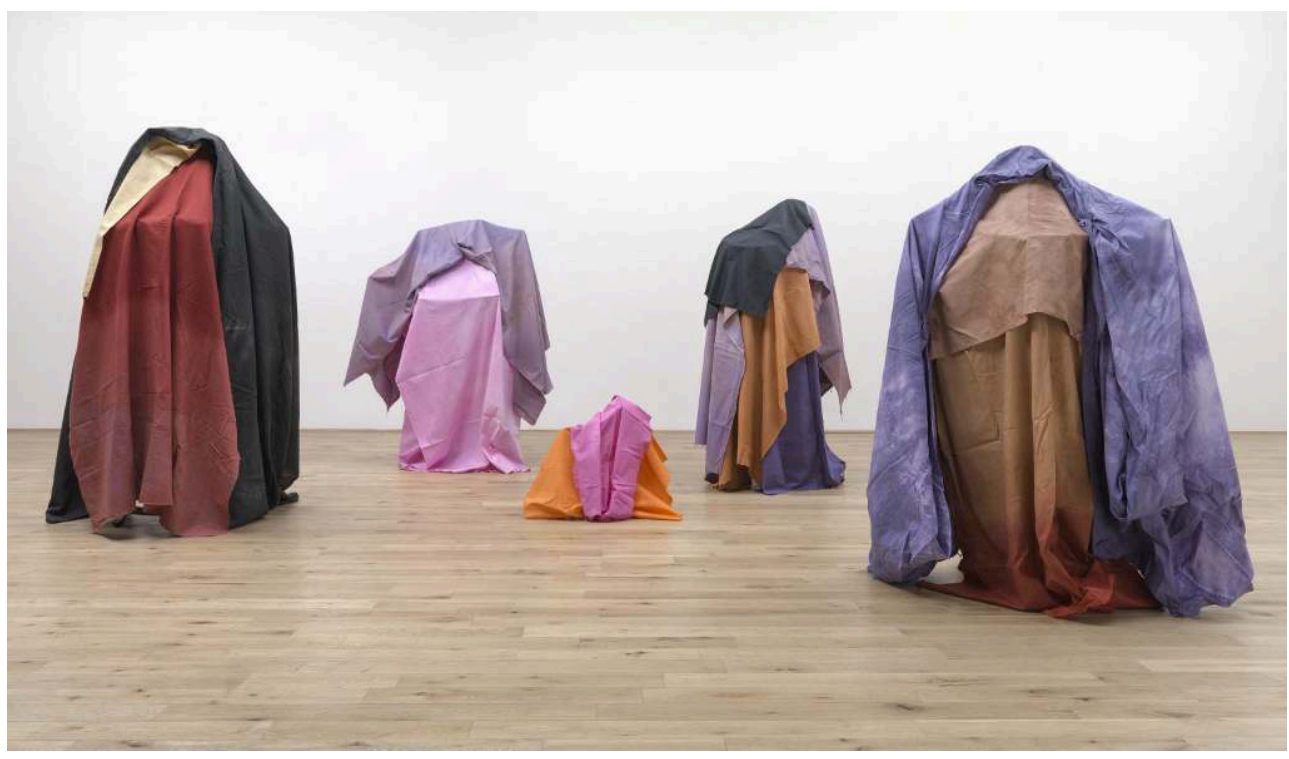

Critics compared the figures to Islamic women, beggars, lepers, and "very poor Hindus." 71 The figures seem consistently to have called forth images of those who are seen as marginalized, without power. Their movements were a poor, restrained, automatic mockery of the freedom and passion usually associated with dance. At the same time, the music, by twelfth-century French composer Perotinus Magnus, and the dramatic setting create a church-like, and medieval, ambience that led some viewers to interpret the work as a criticism of Catholicism. ${ }^{72}$ Then there are the visible electrical cords attached to each figure that add an ominous quality, and to some at the time $L a$ baila mecánica may have evoked images of violent repression, given that, in 1978, Julio César Turbay Ayala had been elected president and, in response to the growth of Marxist guerrilla movements, instituted a Security Statute during his tenure (19781982) that increased the power of the military to detain, interrogate, and judge suspected terrorists, leading to increasing human rights violations like arbitrary detention and torture. ${ }^{73}$

If La baila mecánica is read as a metaphor for political oppression, it becomes a tragic foreshadowing of the artist's own future. Bursztyn traveled to Cuba in 1980 to install $\mathrm{La}$ baila mecánica for an exhibition at the Casa de las Américas in Cuba, then returned to Havana in 1981 when the Galería Latinoamericana hosted the exhibition Dos escultores colombianos, Feliza-Negret. These trips to Cuba aroused the suspicion of the military, and on July 24, 1981, just days after returning from Cuba, Bursztyn was taken from her house in the early morning by members of the military intelligence service. She was detained and interrogated for two days. Not long after her release, and fearing further 
persecution, she sought and gained political asylum at the Mexican Embassy. ${ }^{74}$ After a short stay in Mexico, she settled into exile in Paris, but on January 8, 1982, while having dinner at a restaurant with friends, including also-in-political-exile writer Gabriel García Márquez, Bursztyn suffered a sudden heart attack and died.

\section{Bursztyn in Art Historiography}

41 Critics and art historians consistently note that Bursztyn stood out within the Colombian art scene for her refusal to stick to conventional notions of what sculpture should be and for being the first in the nation to adopt new approaches to sculptureand these qualities are indeed clear and striking. As early as 1974, critics would proclaim Bursztyn's importance as the harbinger of contemporary art, an art without limitations, one that freely expands beyond all boundaries to draw from "the particularities, techniques, and systems of other disciplines." 75 Traba counted Bursztyn as one of three artists who brought Colombian sculpture into the modern age. In an essay about Bursztyn's work, she credits Bursztyn-along with Negret and Ramírez Villamizar-as establishing sculpture's autonomy. ${ }^{76}$ By this, Traba explained, she meant that the sculpture of these three is no longer bound to the service of other institutions through narrative or commemoration. But Bursztyn's work can hardly be seen as belonging, strictly, to modernism as conceived of in terms of a progression toward a self-contained aesthetic object. Nor should her work be valued merely in terms of her contributions to art in Colombia.

Great value is placed, within the historiography of modern art, on the liberating qualities of art and on artistic innovation. If modernism in art is approached as a relative phenomenon that should be considered within a local context (an argument made at times, for example, by Traba ${ }^{77}$ ), Bursztyn holds a crucial place in history as a Colombian modernist, as one of the foremost innovators within her country of origin. However, this interpretation of art history places Colombian art squarely within the discourse of European-American modernism without challenging assumptions of this discourse, for example, that innovation should be seen as a primary value in art, which is strongly associated with a linear, progressive view of art that puts European or U.S. artists in the lead and leaves Latin American artists perpetually behind (as evidenced by Harold Rosenberg's quotation, cited earlier in this article), or with the idea of the artist as genius that is usually also associated with male superiority.

Without ignoring the impact (sometimes shocking) of her art as something unprecedented within its context, and without overlooking her need to deal with dominant discourses on art, it is important, too, to consider how Bursztyn's art may be interpreted as confronting and complicating not just cultural hegemony in Colombia but also certain persistent myths of modern art, in general, to question unilateral discourses of modernism emanating from those places where the ideals (and illusions) of modernity are constructed. Thinking about when, how, and why artists like Bursztyn, at the borders of power, creatively utilized materials and manipulated discourses around them in order to confront power, may help us to decolonialize art history. 


\section{BIBLIOGRAPHY}

ADAMS, Beverly. "Locating the International: Art of Brazil and Argentina in the 1950s and 1960s." Ph.D. diss., The University of Texas at Austin, 2000.

ARANGO, Luz Gabriela. “El proletariado femininoentre los años 50 y 70." In Las mujeres en la historia de Colombia, vol. 2, edited by Magdala Velásquez Toro. Bogotá: Consejería Presidencial para la Política Social; Grupo Editorial Norma, 1995.

BAZZANO-NELSON, Florencia. "Cambios de margen: Las teorías estéticas de Marta Traba." In Dos décadas vulnerables en las artes plásticas latinoamericanas, 1950-1970, by Marta Traba, 9-32. Buenos Aires: Siglo Veintiuno Editores, 2005.

BISHOP, Claire. Installation Art: A Critical History. New York: Routledge, 2005.

BURSZTYN, Feliza. “Soy una obrera y soldadora." Cromos (Bogotá), no. 812 (November 6, 1974).

CALDERÓN SCHRADER, Camilo, ed. 50 años: Salón Nacional de Artistas. Bogotá: Colcultura, 1990.

DIZGUN, John. "Rites of Passage: The Struggle over Jewish Intermarriage and Conversion in Colombia." Shofar 19, no. 3 (Spring 2001): 41-55.

ESCOBAR, Arturo. Encountering Development: The Making and Unmaking of the Third World. Princeton, NJ: Princeton University Press, 1995.

GARCÉS, Alonso, and ÁLVARO Barrios. “Conversación con Alonso Garcés sobre Feliza Bursztyn.” In Orígenes del arte conceptual en Colombia, by Álvaro Barrios, 63-69. Bogotá: Alcaldía Mayor de Bogotá, 1999.

GARCÉS de LLOREDA, María Antonia. “El arte en manos de las mujeres?” Revista Diners (Bogotá), no. 99 (June 1978): 32-35.

GIRALDO, Iáder. "El hippismo criollo: Un movimiento heterodoxo, heterogéneo, heterosexual." Revista Diners (Bogotá), no. 39 (April-May 1970): 74-81.

GIUNTA, Andrea. Avant-Garde, Internationalism, and Politics: Argentine Art in the Sixties. Translated by Peter Kahn. Durham and London: Duke University Press, 2007.

GONZÁLEZ, Miguel. "Las Bienales Gráficas de Cali." Re-Vista del Arte y la Arquitectura en Colombia (Medellín) 2, no. 6 (1981): 33-35.

HANRATTY, Dennis M., and Sandra W. MEDITZ, eds. Colombia: A Country Study, 4th ed. Washington, D.C.: Federal Research Division, Library of Congress, 1990.

JARAMILLO, Carmen María. Figuras del arte moderno en Colombia. Bogotá: Alcaldía Mayor de Bogotá; Fundación Gilberto Alzate Avendaño, 2012.

JARAMILLO Uribe, Jaime. “Obituary: Juan Friede (1902-1990).” The Hispanic American Historical Review 71, no. 1 (February 1991): 137-139.

JIMÉNEZ JIMÉNEZ, Catalina. “Aplicación e instrumentalización de la doctrina de Seguridad Nacional en Colombia (1978-1982): Efectos en materia de derechos humanos." Coleción (Buenos Aires) 20 (2009): 75-105.

LEVI-STRAUSS, Claude. The Savage Mind. Chicago: The University of Chicago Press, 1966.

LEYVA, Camilo, Manuela Ochoa, and Juan Carlos Osorio. Feliza Bursztyn: Elogio de la chatarra. Bogotá: Museo Nacional de Colombia, 2009. Exhibition catalog. 
LONDOÑO, Juan Luis. "Had Kuznets Visited Colombia..." In The Colombian Economy: Issues of Trade and Development, edited by Alvin Cohen and Frank R. Gunter, 49-51. Boulder, CO: Westview Press, 1992.

MESA, Elkin. "Ellos creen ser pioneros de una nueva civilización." Revista Diners (Bogotá), no. 47 (August-September 1971): 84-86.

MIGNOLO, Walter. The Idea of Latin America. Malden, MA; Oxford: Blackwell Publishing, 2005.

NELSON, Richard R., T. Paul Schultz, and Robert L. Slighton. Structural Change in a Developing Economy: Colombia's Problems and Prospects. Princeton, NJ: Princeton University Press, 1971.

PEARCE, Jenny. Colombia: Inside the Labyrinth. London: Latin America Bureau, 1990.

SANTAMARÍA, Ricardo, and Gabriel Silvia LÚJAN. Proceso político en Colombia: Del frente nacional a la apertura democrática. Bogotá: CEREC, 1984.

SMALL, Irene. "Exit and Impasse: Ferreira Gullar and the 'New History' of the Last Avant-Garde." Third Text 26 (January 2012): 91-101.

RAMÍREZ, Mari Carmen. Cantos Paralelos: Visual Parody in Contemporary Argentinean Art. Austin: Jack S. Blanton Museum of Art, 1999.

ROSENBERG, Harold. "International Art and the New Globalism." New Yorker 39 (May 4, 1963): 166-172.

RUBIANO CABALLERO, Germán. Escultura colombiana del siglo XX. Bogotá: Ediciones Fondo Cultural Cafetero, 1983.

SERRANO, Eduardo. Un lustro visual: Ensayos sobre arte contemporáneo colombiano. Bogotá: Museo de Arte Moderno; Ediciones Tercer Mundo, 1976.

TRABA, Marta. “Decálogo de chatarra." In Feliza Burztyn: Chatarras, n.p. Museo de Arte Moderno de Bogotá, 1964. Exhibition brochure.

TRABA, Marta. Dos décadas vulnerables en las artes plásticas latinoamericanas: 1950-1970. Mexico: Siglo XXI Editores, 1973.

TRABA, Marta. “Feliza Bursztyn.” Eco (Bogotá) no. 267 (January 1984): 235-260.

TRABA, Marta. Histéricas: Burztyn. Museo de Arte Moderno, 1968. Exhibition brochure.

TRABA, Marta. Historia abierta del arte colombiano. Cali: Ediciones Museo La Tertulia, 1974.

URIBE ECHEVARRIA, Rodrigo. “Discurso de apertura." In I Bienal Iberoamericana de Pintura Coltejer, 5-9. Medellín: Coltejer, 1968. Exhibition catalog.

URIBE ECHAVARRÍA, Rodrigo. “Empresa privada y cultura.” Colombia Ilustrada (Medellín) 2 (January-April 1971): 25.

\section{NOTES}

1. The same image was also reproduced in Marta Traba, "El primer salon de artistas jóvenes, un éxito," La Nueva Prensa (Bogotá) no. 122 (September 1, 1964): 59-61.

2. The salon was the first in a series held throughout Latin America. For a detailed analysis see Nadia Moreno Moya, Arte y Juventud: El Salón Esso de Artistas Jóvenes en Colombia (Bogotá: IDARTES and La Silueta, 2013). 
3. Walter Mignolo has written extensively on border thinking. Walter Mignolo, The Idea of Latin America (Malden, MA; Oxford: Blackwell Publishing, 2005), 9-10. Other theorists who have influenced my argument are Arturo Escobar, especially Encountering Development: The Making and Unmaking of the Third World (Princeton, NJ: Princeton University Press, 1995) and Gayatri Chakravorty Spivak.

4. On Bursztyn's relationship with César, see Camilo Leyva, Manuela Ochoa, and Juan Carlos Osorio, "Cronología," in Feliza Bursztyn: Elogio de la chatarra (Bogotá: Museo Nacional de Colombia, 2009), 76. On the perceived similarity of her work to that of Jean Tinguely, see Marta Traba, Historia abierta del arte colombiano (Cali: Ediciones Museo La Tertulia, 1974), 189-190.

5. Carmen María Jaramillo, Figuras del arte moderno en Colombia (Bogotá: Alcaldía Mayor de Bogotá; Fundación Gilberto Alzate Avendaño, 2012), 57.

6. Exemplary in this respect, and most influential, was the art criticism of Marta Traba, For a detailed analysis of her criticism, see Florencia Bazzano-Nelson, "Cambios de margen: Las teorías estéticas de Marta Traba," in Dos décadas vulnerables en las artes plásticas latinoamericanas, 1950-1970 by Marta Traba, 9-32 (Buenos Aires: Siglo Veintiuno Editores, 2005).

7. This list is a partial list of artists who won prizes at the prestigious Salón Nacional for abstract artworks in the 1950s. See Camilo Calderón Schrader, ed., 50 años: Salón Nacional de Artistas. Bogotá: Colcultura, 1990. The volume contains examples of art criticism from the period, too, that exemplify the dominance of the aestheticist approach.

8. There were no movements similar to Cubism, Dada, or Surrealism in Colombia, and collage does not appear in Colombian art until the late 1950s. At that time, Carlos Rojas introduced collages, influenced by Cubism and made of cut paper, and in the early 1960s, several artists including Guillermo Wiedemman, Álvaro Herrán, and Leonel Estrada collaged found objects into their paintings. Within all of these works, however, the found objects are used like paint to add color, pattern, and texture, so that their "previous life" virtually disappears. For illustrations, see Jaramillo, Figuras del arte moderno, 68, 71.

9. See, for example, Marta Traba, "Decálogo de chatarra," in Feliza Burztyn: Chatarras, Museo de Arte Moderno de Bogotá, 1964, exhibition brochure. Traba's discussions of arte de la nueva realidad (art of the new reality) clearly are influenced by French critic Pierre Restany and the Nouvelle Realisme he supported in art, launched with a 1960 exhibition and manifesto in Paris.

10. Traba wrote vaguely about their connection to modern life, in general, and that kind of generalization about modernism/modernity in Bursztyn's work has prevailed.

11. Desarrollismo reflects a widely held belief that industrialization followed an evolutionary pattern that was universal. Less affluent countries like Colombia, it was believed, could become more affluent (developed) by following the capitalist models set by wealthy countries such as the United States. Escobar, Encountering Development.

12. This growth was stimulated first by the government's policy of import substitution industrialization in the 1950s-which encouraged local consumer manufacturing to substitute for previously imported goods-and with an export promotion strategy in the 1960s. J.F. Hornbeck, "The Economy," in Colombia: A Country Study, 4th ed., eds. Dennis M. Hanratty and Sandra W. Meditz (Washington, D.C.: Federal Research Division, Library of Congress, 1990).

13. Richard R. Nelson, T. Paul Schultz, and Robert L. Slighton, Structural Change in a Developing Economy: Colombia's Problems and Prospects (Princeton, NJ: Princeton University Press, 1971).

14. "Catholic control over education in Colombia was the strongest in Latin America and even greater than its official powers suggested." Dennis M. Hanratty and Sandra W. Meditz, eds., Colombia: A Country Study (Washington: GPO for the Library of Congress, 1988), 120.

15. This aspect of desarrollismo vis à vis art is clear, for example, in the address made by Coltejer president Rodrigo Uribe Echevarría at the opening of the first Coltejer Biennial. He said, "The progress of a country is measured by the grade of cultural evolution and this is manifested in art," and "we are well able to dedicate part of our force to artistic improvement, without 
sacrificing our possibilities of economic development, in order that the physiognomy of Colombia doesn't end up soon disfigured by a purely material aspect...." In this speech and other statements, he explains his belief that democracy suffers with spiritual (cultural) impoverishment, which in turn is bad for business. Rodrigo Uribe Echevarria, "Discurso de apertura," in I Bienal Iberoamericana de Pintura Coltejer (Medellín: Coltejer, 1968), 5.

16. Ricardo Santamaría and Gabriel Silvia Lújan, Proceso político en Colombia: Del frente nacional a la apertura democrática (Bogotá: CEREC, 1984). The Frente Nacional, put in place after the dictatorship of Gustavo Rojas Pinilla, reorganized the government to avoid both dictatorship and the kind of partisan violence that marked the period known as La Violencia (1948-1958). It guaranteed the Liberals and Conservatives an equal share in power.

17. Juan Luis Londoño, "Had Kuznets Visited Colombia...," The Colombian Economy: Issues of Trade and Development, eds. Alvin Cohen and Frank R. Gunter (Boulder, CO: Westview Press, 1992), 49-51.

18. Jenny Pearce, Colombia: Inside the Labyrinth (London: Latin America Bureau, 1990).

19. Biographical information comes from Leyva, Ochoa, and Osorio, "Cronología," 74-93.

20. John Dizgun, "Rites of Passage: The Struggle over Jewish Intermarriage and Conversion in Colombia," Shofar 19, no. 3 (Spring 2001): 47.

21. Examples include Juan Friede, a merchant who also became one of Colombia's most influential and respected historians. Jaime Jaramillo Uribe, “Obituary: Juan Friede (1902-1990)," The Hispanic American Historical Review 71, no. 1 (February 1991): 137-139. Another example is Casimiro Eiger, art critic and gallerist. Like Bursztyn's parents, both Friede and Eiger were Polish Jews.

22. As described by Walter Engel, "Felisa Brustyn [sic.] y Gloria Daza: Divagaciones sobre crítica, mentira y honradez en el arte," El Espectador (Bogotá), September 2, 1961.

23. Ibid.

24. For example, see Germán Rubiano Caballero, Escultura colombiana del siglo XX (Bogotá: Ediciones Fondo Cultural Cafetero, 1983), 138, and Camilo Leyva, "Poesía," in Feliza Bursztyn: Elogio de la chatarra, 12. A photograph of one, titled Luna llena, appears in the retrospective exhibition catalog Bursztyn (Bogotá: Museo de Arte Moderno, 1974). Another from c. 1961, now in the collection of Alicia de Villar, appears in the retrospective exhibition catalog Feliza Bursztyn: Elogio de la chatarra, cat. 1.

25. Engel, "Felisa Brustyn [sic.]." All translations from the Spanish are by the author.

26. Ibid.

27. Artists who adopted poor, degraded materials in the 1960 s included not just the aforementioned Nouvelle Réalistes in Paris, but also the Argentines Antonio Berni, Alberto Heredia, and the Arte Destructivo artists (1961) and slightly later the Arte Povera artists of Italy (1967-1972), among others.

28. Traba, Historia abierta, 189.

29. On Bursztyn's decision to use junk as material, see Ramírez Heredia, "Feliza Bursztyn, habla de camas y otras cosas," El Tiempo-Lecturas Dominicales (Bogotá), August 24, 1975: 8.

30. Harold Rosenberg, "International Art and the New Globalism," New Yorker 39 (May 4, 1963), 172, quoted in Beverly Adams, "Locating the International: Art of Brazil and Argentina in the 1950s and 1960s" (Ph.D. diss., The University of Texas at Austin, 2000), 158.

31. Rosenberg did not name a particular Mexican artist in this article; rather, he was making a general, theoretical statement. The artists he mentioned, with the exception of Roberto Matta and two Japanese artists, are all U.S.-American or European.

32. Eduardo Serrano, "La intuición artística de Feliza Bursztyn," El Tiempo-Lecturas Dominicales (Bogotá), September 9, 1973; republished in Eduardo Serrano, Un lustro visual: Ensayos sobre arte contemporáneo colombiano (Bogotá: Museo de Arte Moderno; Ediciones Tercer Mundo, 1976), 82-87. 33. Londoño, "Had Kuznets Visited Colombia...," 49-51. 
34. Claude Levi-Strauss, The Savage Mind (Chicago: The University of Chicago Press, 1966), 17. Levi-Strauss applied bricolage to his analysis of "primitive" cultures; however, it is a word that describes a practice that, as he explained, was common in France and therefore is not limited to an understanding of indigenous cultures. My analysis of Bursztyn's work in terms of bricolage is indebted to Mari Carmen Ramírez, who used the concept to present the work of Argentinean artists in Cantos Paralelos: Visual Parody in Contemporary Argentinean Art (Austin: Jack S. Blanton Museum of Art, 1999), 63-65.

35. Feliza Bursztyn, "Soy una obrera y soldadora," Cromos (Bogotá), no. 812 (November 6, 1974).

36. In 1966, only $5 \%$ of workers were women in Colombian factories for metal products, machines, and equipment. Luz Gabriele Arango has shown that the introduction of the methods of industrial engineering techniques in the late 1950s in Colombia led to a decline in the overall presence of women in all kinds of factories, even in the textile industry where previously $72 \%$ of the workers had been women. Luz Gabriela Arango, "El proletariado femininoentre los años $50 \mathrm{y}$ 70," in Las mujeres en la historia de Colombia vol. 2, ed. Magdala Velásquez Toro (Bogotá: Consejería Presidencial para la Política Social; Grupo Editorial Norma, 1995), 506, 512.

37. There were some successful women artists. Interestingly, however, the most famous women in the art world were not artists but art critics or museum or gallery directors, Traba foremost among them. See María Antonia Garcés de Lloreda, "El arte en manos de las mujeres?" Revista Diners (Bogotá), no. 99 (June 1978): 32-35. Although this article was written in 1978, it documents a situation that was the same in the 1960 s.

38. Alonso Garcés, "Conversación con Alonso Garcés sobre Feliza Bursztyn," interview by Álvaro Barrios, in Álvaro Barrios, Orígenes del arte conceptual en Colombia (Bogotá: Alcaldía Mayor de Bogotá, 1999), 64.

39. It appears that Judith Márquez exhibited a motorized sculpture in 1957 at the Galería El Callejón, as discovered recently by the research group En un lugar de la Plástica; see Plástica 18 (Bogotá: Universidad de los Andes y Fundación Gilberto Alzate Avendaño, 2007), 27, as cited by Jaramillo, Figuras del arte moderno, 120, note 85.

40. Calderón, 50 años, 147.

41. Leyva, Ochoa, and Osorio, "Cronología," 79-80.

42. Betha Beatriz de Fernández de Soto, "Esculturas con sonido exhibe Feliza Bursztyn," El Tiempo (Bogotá), February 29, 1968: 16. Her collaborator's name was Albano Ariza.

43. Traba compared them to Tinguely's machines in Historia abierta, 189-190.

44. Manuela Ochoa has recently discussed Freudian ideas about hysteria in relation to Las histéricas: Manuela Ochoa, "Movimiento," in Feliza Burzstyn: Elogio de la chatarra, 14.

45. Traba, Historia abierta, 190. In this text, Traba mentions that some critics believed Las histéricas would have been better without movement

46. Nohra Parra Martínez, "Experimento plástico en arte moderno," El Tiempo (Bogotá) December 11, 1968: 24.

47. In her book Dos décadas vulnerables en las artes plásticas latinoamericanas: 1950-1970 (Mexico: Siglo XXI Editores, 1973), Traba named eroticism as one of the three most radical developments of art in the decade of the 1960s. Traba did not publish any critique of Bursztyn's art that discussed its sexual connotations until she published Dos décadas. By then, she was writing about sexuality in art, drawing heavily on the theories of Marcuse (219-21).

48. Ochoa, "Moviemento," 17.

49. Again, Uribe's addresswasoa, and Osorio, 'lite) is exemplary. from the period, as well, that exemplify the dominance of the aestheticist approa at the biennial is exemplary. Also see Rodrigo Uribe Echavarría, "Empresa privada y cultura," Colombia Ilustrada (Medellín) 2 (January-April 1971): 25. Desarrollismo drove cultural development in other Latin American countries during the 1960s, as well. There are excellent studies, in particular, that consider art within the context of developmentalist theory and policy in Argentina and Brazil. See, for example, Andrea Giunta, 
Avant-Garde, Internationalism, and Politics: Argentine Art in the Sixties, trans. Peter Kahn (Durham and London: Duke University Press, 2007) and Irene Small, "Exit and Impasse: Ferreira Gullar and the 'New History' of the Last Avant-Garde," Third Text 26 (January 2012): 91-101.

50. Álvaro Barrios, a young artist who participated in Espacios ambientales, visited Italy in the summer of 1968, where he saw an exhibition of environments called Lo spazio dell'immagine in Foligno, and he suggested to Traba, the de-facto director of the Museo de Arte Moderno de Bogotá at the time, that Colombian artists should create something similar. Barrios, Orígenes del Arte Conceptual, 16.

51. Miguel González, "Las Bienales Gráficas de Cali," Re-Vista del Arte y la Arquitectura en Colombia (Medellín) 2, no. 6 (1981): 33.

52. Margarita Vidal, "Feliza Bursztyn," Vanidades (Bogotá), August 21, 1973; cited in Camilo Leyva, Manuela Ochoa, and Juan Carlos Osorio, "Glosario," in Feliza Bursztyn: Elogio de la chatarra, 100.

53. Leyva, Ochoa, and Osorio, "Chronología," 81.

54. G. de Bethencourt, "Ha nacido un arte nuevo: El de los 'Espacios ambientales," Revista Pueblo (Bogotá), March 22, 1969: 5-6; cited in Leyva, Ochoa, and Osorio, "Glosario," 99.

55. Bursztyn and the other artists of Espacios ambientales certainly were not alone within the context of 1960s art globally in their desire to create a more inclusive kind of artistic experience that ideally might liberate the viewer. For example, the ways in which Brazilian artists Lygia Clark and Hélio Oiticica expanded their work from 1963 onward reflects a similar desire, and Oiticica began to create environments in 1967 with his Tropicalia works. For a global overview of an "art of environments" (installation art) as well as a critique of their ideals of inclusion through participation, see Claire Bishop, Installation Art: A Critical History (New York: Routledge, 2005).

56. Quoted in Barrios, Orígenes, 17; originally published in Magazín Dominical (Bogotá), December 8,1968 .

57. Ibid.

58. Ibid.,18.

59. Ibid., 21; originally published in El Espectador (Bogotá), December 15, 1968.

60. Traba's view on art and politics would change throughout her career, and she expressed her famous "thesis of resistance" some years later, in Dos décadas vulnerables. See Bazzano-Nelson, "Cambios de margen," 9-32.

61. For such a comparison, see Leyva, Ochoa, and Osorio, "Cronología," 83-84.

62. Luis Ernesto Arocha, Alizef, 1971, 8-minute, black and white, $16 \mathrm{~mm}$. It can be viewed on the internet at La Diferencía: Artes Electronicas en Colombia, http://www.ladiferencia.org (last accessed June 30, 2013).

63. The growing visibility of and interest in hippismo at the beginning of the 1970s is reflected newspaper and magazine articles of the time, for example: Iáder Giraldo, "El hippismo criollo: Un movimiento heterodoxo, heterogéneo, heterosexual," Revista Diners (Bogotá), no. 39 (April-May 1970): 74-81, and Elkin Mesa, "Ellos creen ser pioneros de una nueva civilización," Revista Diners (Bogotá), no. 47 (August-September 1971): 84-86.

64. Bursztyn had exhibited some prototypes of Las camas, including two shown in separate exhibitions in 1972. Leyva, Ochoa, and Osorio, "Cronología," 85.

65. “Análisis de la obra de Feliza Bursztyn,” El País (Cali), September 25, 1974.

66. Marta Traba, Histéricas: Burztyn, Museo de Arte Moderno, 1968, exhibition brochure, and Parra Martínez, "Experimento plástico en arte moderno," 42.

67. Nicolás Suescún, “Las camas de Feliza en el Museo de Arte Moderno el 26," El Tiempo (Bogotá), March 24, 1974.

68. Ibid.

69. Marta Traba, “Feliza Bursztyn: Imaginación en escultura," El Tiempo (Bogotá), September 19, 1974. 
70. On this influence, see Bazzano-Nelson, "Cambios de margen," 9-32. On the liberating qualities of eroticism in art, see Traba, Historia abierta, 191.

71. Compared to Islamic women:“Feliza y su 'Baila Mecánica,” El Tiempo (Bogotá), April 5, 1979:1B; compared to beggars, lepers, and very poor Hindus: Nicolás Suescún, "Feliza y sus 7 pecados capitales," El Tiempo (Bogotá), April 27, 1979.

72. Colombian artist Miguel Angel Rojas, for example, interpreted the work in this way (conversation with the author, June 5, 2013). Note that the title of Suescún's review, cited above, links the seven figures to the Catholic faith's "seven deadly sins."

73. Catalina Jiménez Jiménez, "Aplicación e instrumentalización de la doctrina de Seguridad Nacional en Colombia (1978-1982): Efectos en materia de derechos humanos," Coleción (Buenos Aires) 20 (2009): 75-105.

74. This brief account of her detention, exile, and death comes from Leyva, Ochoa, and Osorio, "Cronología," 90. According to this source, after the search and detention military officials sent her a citation calling her before a military judge for charges of illegal possession of firearms, for an old and unserviceable pistol they found in her house.

75. Eduardo Serrano, "La intuición artística de Feliza," Revista Dominical, April 7, 1974: 3.

76. Marta Traba, “Feliza Bursztyn,”Eco (Bogotá) no. 267 (January 1984): 237.

77. As in Marta Traba, "Defensa del sí y defensa del no," Magazín Dominical (Bogotá), December 8, 1968, 14 .

\section{ABSTRACTS}

This article analyzes the sculpture of Colombian artist Feliza Bursztyn (1933-1982) through the lens of decolonial theory. Bursztyn has entered the canon of Colombian art history as a key modern artist, but to place emphasis primarily on her formal innovations as they contributed to the development of modern, autonomous art in Colombia is to risk minimizing the ways in which her work challenged cultural hegemony and European-American discourses of modernity. Her art can be interpreted as problematizing the assumption that "development" is the answer to "underdevelopment," that modernity can be universally beneficial. In their confrontations with dominant power structures in Colombia that sought to control class and gender relations and morality, Bursztyn's work exposed modernity's dark side, coloniality.

Este artículo analiza la escultura de la artista colombiana Feliza Bursztyn (1933-1982) a través del lente de la teoría decolonial. Si bien Bursztyn ha entrado en el canon de la historia del arte colombiano como una artista moderna clave, realizar un énfasis demasiado fuerte alrededor de sus innovaciones formales, y de la contribución que estas implican para el desarrollo del arte moderno y autónomo en Colombia conlleva el riesgo de minimizar las maneras en que su obra desafió la hegemonía cultural y los discursos europeo-americanos de la modernidad. Su arte puede interpretarse mejor como una problematización de la suposición según la cual el "desarrollo" es la respuesta al "subdesarrollo", que la modernidad puede ser universalmente beneficiosa. En sus confrontaciones con las estructuras de poder dominantes en Colombia que trató de controlar las relaciones de clase, género y moral, la obra de Bursztyn expone el lado oscuro de la modernidad, la colonialidad. 
INDEX

Palabras claves: Bursztyn (Feliza), teoría, junk sculpture, kinetic art, arte colombiano, historia Keywords: Bursztyn (Feliza), decolonial theory, junk sculpture, kinetic art, Colombian art history

\section{AUTHOR}

GINA MCDANIEL TARVER

Assistant Professor of Art History, School of Art \& Design, Texas State University

gt17[at]txstate.edu 